\title{
SOCIAL JUSTICE AND THE COURTS
}

Suggested by "Our Judicial Oligarchy," by" Gilbert E. Roe, with Introduction by Robert MI. La Follette, New York,

B. W. Huebsch, igr2.

By Theodore Schrocder of the New York Bar.

This book is a most thoughtful and important part of current literature clevoted to the criticism of our judiciary. That, by usurped power, our courts have established a "Juclicial Oligarchy," Mr. Roe tries to prove, in part, by pointing to the judicial practice of declaring legislation unconstitutional, and the class conscious manner in which that power has been exercised. Some of the critics of our courts assert positively, that ours are the only courts in history that ever assume to annul State or national-statutes. IIr. Roe implies that such a power for annulling acts of Parliament is unknown to the English judicial systen. I deem it desirable that this assumption and the other more positive statement shall not go unchallenged, lest persistance of reiteration shall pervert history, and create in the public mind some unwarranted predisposition.

"Magna Charta (Chap. 29) declares that Right and Iustice shall not be sold, nor clenied, nor clelayed to any man. Also, that touching 'the free liberties and free Customs' of the peop'e. 'neither the King, nor his heirs, shall procure or do anything whereby they shall be infringed or broken: and if anything be procured by any person, contrary to the premises, it shall be had of no force or cffect.' This Charter having been confirmed byTivo and Thirty acts of Parliament, all these are consequent!y alike declaratory of fundamentals." 1

Many times, before the American Revolution, have law-writers and enactments of Parliament declared that laws and juclgments which contravened the Great Charter were a nullity:" Review-

${ }^{1}$ Cartwright's, The English Constitution Produced and Illustrated, p. 133, Ed. 1823.

25th Edward I. Stat, 1, Cap. 2; 34th Edward I. Stat. 4, Cap. 4: 25th Edward III. Stat. 5, Cap. 4; 42d Edward IIT., Cap. 1; 3d Henry IV.. Stat. 2; 2d Henry VII., Cap. 1; 1st Henry IV. 
ing and summarizing these authorities, John Cartwright expresses himself thus:

"From the foregoing premises, this conclusion is inevitablethat there is a legal, just, and peaceable resistance to unconstitutional Statutes, and illegally=exercised powers, incumbent on all men to make, and which, for the public good and public peace, were best made by the People when serving on Juries for the enforcement of all just Laws, aided by the Justices on the Bench; as in the noble instances of Wray and Dyer in the time of Elizabeth.

"It being the office of the King's Justices=-not jus dare, but jus dicere or in English-not to make but to declare the law; it follows that, when a penal statute is doubtful of equivacal, the Justices on the Bench are not to interpret, which in that case is equivalent to making the Law, but, in conjunction with the Jury, to suspend the enforcement, and refer it back to the Legislature, who alone, in such a case, are competent to 'amend and explain?" their own imperfect, doubtful, or equivgeal Acț. This course is emphatically pointed out and enjoined by the $\mathrm{r} 3^{\text {th }}$ Edrward I., cap: 8 , in which it is declared and enacted, that 'Defaults shall be presented to the Justices assigned, and after, by them to the King, and the King zeill provide remedy', that is, through the medium of the Legislature; for in the Norman=taught dialect, it is the King whe is said to make the laws, although forsoeth 'with the adyice and consent' of the Legislature. What defaults can be so prejudigial to the public, as laws liąple to misinterpreta= tion? ?:3:3

Out of such considerations arose the ancient maxim: " $\mathrm{Ubi}$ jus incertum ibi jus millum." Lor Auckland, in $177 \mathrm{r}$, exhibited the application of this maxim in the follewing language; "Under the act ${ }_{4}$ Geo. II. c. 6, stealing sheep ' 9 r other cattle' wąs made felony without benefit of clergy; but these general words 'or other cattle being considered as too vagute to greate a capital offense, the act was properly holden to extend only to sheep."s Our American courts have many times held statutes to be uncon-

3 The English Constitution Produced and Illustrated, p. 136.

4 Where the law is uncertain there is no law.

s Principles of Penal Law, pp. 312-314. 
stitutional for uncertainty in the criteria of guilt ${ }^{6}$ and as appears from the above citations they could have found plenty of prerevolutionary precedent for doing so.

I resume my quotations from Cartwright and append his foot notes. "Against the Law of Reason, or against Justice, there is no prescription, or opposed Statute, or Custom; but if any such be made, they be not Statutes nor Customs, but Corruptions. ${ }^{7}$ Corruptions are things voids and against Justice. ${ }^{\mathbf{s}}$ Statutes cannot exist either against Reason, or the Law Divine. ${ }^{9}$ Laws incompatible with the Constitution are in themselves void. ${ }^{\mathbf{1 0}}$ Whatever the Legislature doth shall be holden for nought, whenever it shall enact that which is contrary to the Rights of Nature, or the principles of the Constitution. ${ }^{11}$ When the Legislative power exceeds its limits, its act is no more, as to right and authority, than the act of a private society against the will of the Community. ${ }^{12}$ Although four Acts of Parliament had passed, that persons charged with treason in Ircland might be tried in England, yet when attempted in the reign of Elizabeth, it was declared by Wray and Dyer, Justices, with the entire concurrence of Gerrarde, Attorney-General, that those Acts being contrary to the Constitution, were not Law, and therefore could not be carried into execution. ${ }^{13}$ Empson and Dudley, who had pillaged the paople under an Act of Parliamcnt made for filling the Exchequer, were, for so doing, in the end, hanged as felons; because the pretended Statute (II Henry VII., Chap. I5) which they had put in force, was contrary to the Constitution, and subversive (as Sir Edrvard Coke observed) of 'the Birth-right of the Subject'; and consequently it was a corruption which, when brought to the test, was to be 'holden for nought'.

"There not having existed in time past any correct and authorized Definition of the English Constitution, which might serve

- See cases review in Chapters 18-21 of "Obscene Literature and Constitutional Law"; also, Czarra v. Medical Sup., 25 App. Cases, D. C., 443; United States v. Capital Traction Co., 34 App. Cases, D. C., 592.

'Doctor and Student, Cap. ii, p. 5 and 6, 17th Ed., by Miuchall, 1787.

$s$ Ib. Edition of 1663 , p. 5 .

9 Doctor and Student, 17th Edition by Muchall, 1787, Chap. 10.

${ }^{10}$ Loft's Elements of Universal Law, 291.

11 Proeme to Vol. 2, Coke's Institutes of the Laws of England; Sharp's, Declaration of People's Rights, 236, Lond. 1774.

12 Loft's, Elements of Universal Law, 173.

13 Sharp's, Declaration of People's Rights, 193, Lond. 1774. 
as a criterion for clistinguishing between those Lares that, as fundamental, were unchangcable; and those which were mere rules of temporary expedience, liable to change with circumstances, and therefore altcrable; Lawyers and Statesmen had perhaps no better way to express themselves than as they did, when the cleclared object was, to secure 'Rights and Liberties'; yet it is obvious that on those occasions they intended to speak of what was unchangcable, although using the ambiguous word Law; for it cannot be supposed they put Rights and Liberties on a levcl with Ale-houses or Bawdy-houses, Calves or Cabbage, Witches or Enchantments, Kettles or Frying-pans, the Apparel of a ploughman or the Velvet Cap of a Inight; all which and the like, ten thousand times told, were the subject of Law. The Bill of Rights and Liberties, that was passed for consolidating the Revolution of 1688 , which expelled a King on account chiefly of having suspended wholesome Laws in support of Rights and I.iberties, if not declaratory of thcir constitutional unchangcablcncss, was a bubble and a fraud.

"Mrr. Justice Hotham observes, that, even an Act of Parliament made against natural equity is void in itself, for the laws of Nature are immutable, and leges legum, that is, they are lazos that goz'crn the law'; an expression equivalent to saying, 'The Constitution is a laze to the Lcgislature, zohich it must not disobey.'

"Plowden, in pP. 398-400, has reported a variety of cases, wherein Acts of I'arliament were esteemed void in Laze, through the reant of Truth in their recitals.

"The last authority, as well as that of Dyer, ranks high; for Coke, in his preface to his $2 \mathrm{~d}$ vol. of Reports, says, 'To the former Reports you may add the c.rquisite and claboratc Commentaries of Master Plozuden, a grave man and singularly well-learned; and the summary and fruitful observations of that famous and most reverend Judge, Sir J. Dyer, Knight, late Chief Justice of the Common Pleas.'

"For effectually illustrating the duty of firmly resisting error or corruption, or arbitrary power, under the cloak of Laze, it is convenient to put a strong case. Thus, in the case of nurder, Blackstone says, 'If any human Law should allow or enjoin us to commit it, we are bound to transgress that human Law, or else we must offend both the natural and the divine. ${ }^{14}$ 1793.

I* Blackstone's Commentaries, Vol. 1, p. 42, Christian's Ed., Lond. 
"It being obvious that Laws in violation of inhercut Rights, or in subversion of sacred Liberties, do alike offend against the 'natural and divine Law', as laws against life itself; it follows, that we are alike bound to disobey and resist all such violations and subversions.

"The Prince of Orange, in his celebrated Declaration prelusive to his entcring England, laid great stress on the Courts of Law having been wickedly perverted to answer the purposes of tyranny, and, on the insufferable oppressions of the People in consequence thereof. expressly declared that none were bound to acknowledge or obey the Judgments of the wicked judges of that day, as being. equally with spurious statutes, null and void in themselves, or. to kcep to his own words, 'of no force and efficacy." "15

In the American Colonies the foregoing limitations on the legislative power were supplemented by the limitations imposed by the American Charters. "Questions sometimes arose *** whether the statutes made by these assemblies werc in excess of the powers conferred by the Charter; and if the statutes were found in excess, they were held invalicl by the courts,- that is to say, in the first instance, by the colonial courts, or, if the matter was carried to England, by the P'rivy Council." "1; I taise it these anthorities abundantly show that the courts of England did annul legislation violative of Magna Charta, natural justice, or other funclamental restrictions on the legislative authority, such as the charters which preceded and stood in lieu of our present constitutions.

Lnder the newly organized States these examples were followed. ${ }^{1 \top}$

Mr. Roe says some things upon free speech in relation to criticism of our judiciary which needs emphasis in some parts and criticism in others. In suggesting the recall of Jurlges as a useful remedy he uses this language: "This means discussion and freedom for discussion. It means that judicial decisions shall be

15 John Cartwright. The English Constitution Produced and Jllustrated, pp. 129-136; Ed. of 1823.

${ }^{16}$ Bryce, The American Commonwealth, r. 1, pp. 243-415.

17 Treictt a'. Needen, R. T., (1786) ; Bayard ''. Singlcton. Martin (N. C.), p. 48 (1787). For extended discussion see Taylor. Juriscliction and Procedure of the Supreme Court of the United States. pp. 2-5: Cooley. Constitutional Limitations, 36 ‥ 1. 
subjected to the same public scrutiny that is applied to the votes and speeches of nembers of Congress or other legislatures. $* * *$ Respect for courts and obedience to their decrees must rest upon some other basis than a fear of contempt proceedings, on a veneration for Judicial mystery. The judge who mistakes damage to his vanity for an injury to public welfare proves his unfitness for public office. *** That the process of contempt is used to violate the fundamental guaranties of freedom of speech and of the press is freely charged, and it certainly is subject to great abuse."18

In this connection Mr. Roe (pp. 5 and I99) makes a review of an interesting case $^{19}$ as to some extent illustrating the Judicial abuses of the power to punish contempt. Mr. Roe follows his judicious comment on the Thatcher Case with this statement: "If the courts do not speedily abandon the practice of punishing, under the guise of contempt proceedings, those who have merely incurred the displeasure of the judges, the Congress and State legislatures are likely to take the whole matter in hand and regulate the subject by statute and see to it that there shall be the same right to discuss the acts and abilities of judges that obtains in the case of other public servants."

If Mr. Roe had looked more deeply into the machinations of our "Judicial Oligarchy" he might have found that it brooks no interference with its regal "prerogatives". Statutes which preclude courts from exercising the common-law arbitrary power to punish critics have been held unconstitutional in several States. ${ }^{20}$ In this respect our "Judicial Oligarchy" is even worse than Mr. Roe dreamed.

To certain blind-as-bats reformers, Mr. Roe, after elaborate argument, makes this summary: "The real basis of complaint is not that judges haven't enough power, but that they have too much; it is not so much that litigation is costly as that its results

${ }_{18}$ The growth of Judicial Despotism, Twentieth Century, July, 1910; The Growing Despotism of Our Judiciary, The Arena, July, 1908; The Law of Constructive Contempt, by John L. Thomas, St. Louis, 1904.

${ }^{19}$ In re Thatcher, 80 Ohio State, 492; 83 Ohio State, 246; 89 Northeastern Reporter, 39.

20 State v. Morrill, 16 Arkansas, 384; State v. Frew, 24 W. V., 416; Bradley v. State, 50 L. R. A., 691; Com. v. Carter, 45 L. R. A., 310; State ex inf. Crow v. Shephard, 177 Mo., 79, 76 S. W., 79, 99 Am. State Rep., 624. For a good criticism of this last decision see, "The Law of Constructive Contempt," by John L. Thomas. The above cases were recently followed in Pennsylvania in a case now pending on appeal. 
are unsatisfactory; it is not that justice is delayed, but that it is denied. The purpose of the courts should not be so much to render speedy decisions as to give just judgments.

"Limiting the right to appeal may conceal these wrongs, but it will not correct then. Greater haste in judicial action will hardly contribute to a wiser or more just result. MIore arbitrary power vested in a judge may decrease the number of cases in which he can be reversed but it will not make his wrong decisions right. It will only increase the number of wrong decisions and take away the possibility of correcting them."

In interpreting this language, by which our author clarifies the issues, it is necessary to remember that Mr. Roe is concerning himself primarily with social justice in the broader sense, where the judge's theories of economics, and politics and his class prejudices are involved and as he proves, are controlling. Thus construed and so far, it is my opinion that he has proven that our courts are a failure. This brings him to the recall of judges as a remedy for the ills set forth. The superficial source of the evil complained of, he points out in the same paragraph by which he answers one criticism of the recall theory. He says:

"The other half of the argument against the recall of judges, namely that the possession of such power by the people will intimidate the courts into making wrong. decisions, has, if possible, less to support it than that alreacly considered, and is, besides, the severest arraignment ever made of the judiciary of this country. If it is true that judges will serve the power that controls the tenure of their office to the extent of rendering wrong decisions when that power is the people, is it not true that they will be equally subservient to any other power which controls their official life?" That other power, at present, is the "big interests" who are the chief beneficiaries of legalized injustice and vested wrongs, and which are the "invisible government" behind the boss and the political machine of ill fame.

Mr. Roe fails to mention that to have the "invisible government" by big business control the appointment for life, and the promotion of such judges, because it is beyond undoing, is even more pernicious than that same control of judges elected for short periods:

By an abundance of recent discussion it is made very plain that the consciously corrupt judge is too infrequent to be half as dan- 
gerous as the conscientious judge, who acquired his judicial predispositions through the sympathies instilled by a corporation practice and other schools of privilege. The consciously corrupt judge has a corrupted motive in but few cases, while the judge conscientiously predisposed to favor privileged classes carries that predisposition into every case by him considered. The conscientious judge who believes in class privileges and undemocratic distinctions is therefore more pernicious than the judge who is occasionally corrupt. It is precisely these conscientious judges who most zealously block the progress of our ever refining sense of social justice, and by the blind following of ancient precedents, they seem to sanctify their wrongs. To my mind it is plain that the true cause of complaint is not so mcuh that a power exists to declare laws unconstitutional, as the manner in which that power has been exercised.

This brings me to another question, and I think the most important question connected with this controversy and one which has been neither asked nor answered. Why is it that a corporationbred lawyer quite uniformly remains an unconscious corporation attorney while performing judicial functions. I am convinced that only a small percentage are justly chargeable with conscious dishonesty, even of the kind which is merely intellectual. Why is the conscientious judge unable to get away from those early sympathies first excited by his youthful cupidity? And why, in spite of his efforts to be just, does he nearly always see legal problems through the eyes of the privileged classes? That he does this is what Mr. Roe and others prove quite clearly.

Candidly; I believe the answer to my questions is this: Our judges are at least so far intellectual bankrupts as to have little or no social consciousness ${ }^{21}$ and minds utterly devoid of anything like a scientific conception of law, or any knowledges of what is meant by a scientific method for the ascertainment of truth. Elsewhere I have undertaken to indicate the requirements of the scientific method as applied to law. ${ }^{22}$ A conscious and intelligent application of the scientific method would preclude practically all the evils complained of, and nothing else can give us relief. So long as our judicial opinions are formed by the mental processes

21 I use these words as they are defined in Prof. Fite's "Individualism."

22 Interstate Commerce, Employer's Liability and the Supreme Court, in Govermment, June, 1908, and American Law Revicw', June, 1908. 
of the intellectual bankrupts these will only be crude justifications of predispositions acquired through personal or class interests and sympathy, "moral" superstitions, or whim and caprice. It follows that courts decide cases without declaring or applying "law", in any scientific sense, because they misuse empirical inductions and stupid dogmas for legal principles, and often times they even mistake a figure of speech for an anology, or an illustration for argument. Thus from incompetence courts produce unsatisfactory results. A like incompetence among critics makes them misçonceive the issues and misdirect their criticism. Thus it comes that we hear so much uncritical criticism of the courts for technical devisions. The unintelligent critic sees the effect of the technicality only as it produces results contrary to his predispositionis, usually founded only on sympathies and blind emotions. Ordinarily, I think, a wider vision would enable them to see the "technicality" as but a special application of a general principle which it is important to maintain inviolate for the sake of uniformity in the rules which shall govern human conduct and liberty. It is this like incapacity which recently prompted the demand, from an influential source, that laymen shall be put upon our appellate benches in order that "equity" and "justice between man and man" may prevail.

Such suggestions for the reform of our judiciary come from laymen, and evidence the same kind of intellectual bankruptcy, which so frequently induces appellate courts to affirm judgments because "substantial justice" has been done, which they judge to be the fact in spite of the disregard of those general principles and axioms by which the best minds sought to preclude injustice. In this aspect some reforms resolve themselves into mere stupid suggestion from one group of incompetents for the reform of others, whose faults also are due to incompetence of a lesser degree. The proposed remedy is but more of the disease.

Such reformers see every controversy as an isolated phenomenon, because they are unable to think in generalizations, and so see no relation of principle between different cases. This same incapacity for coördination makes these critics and many judges unable to see that uniformity, generality and certainty in all the state-enforced rules of conduct, is the most important safeguard against despotism. Take away the demand that judicial decisions shall conform to general principles, and then you destroy the best 
method by which corrupt motives can be detected and pernicious despetism curtailed.

"To have no rule of dividing controyersies, but only the rule of mere equity, is to begin the world again ; to make choice of that rule, which out of mere necessity was made use of, in the infancy of the state, and indigency of laws, and now is the only rule among Indians and Hottentots in Africa; and to set up this rule, after laws are established, and leave the matter at large, is it not rather unravelling, by unperceived degrees, the fine and close texture of the law of England, which has been for so many hundred years making and which made a noble lord and a great and learned chancellor say one, "if Equity were too much encouraged, it would in time eat out the heart of the common law of England, "=?

"Freedom of men under government is to have a standing rulc to live by, common to every one of that society, and made by the legislative power erected in it; a liberty to follow my own will in all things where the rule prescribes not; and not to be subjegt to the inconstant, uncertain, unknown, arbitrafy will- of angther man? 3

"The discretion of a judge is the law of tyrants; it is always unknown; it is casual, and depends upon constitution, temper, passion. In the best, it is oft times caprice; in the worst is every vice, folly and passion to which human nature is liable."2s

To the extent of believing that the highest ideal of right ean only be attained through the general application of fixed, uniform and certain principles, I am in accord with the opponents of the recall of judges and of judicial opinions: I have alfeady explained that owing to a want $\mathrm{g}$ intelligence as to the scientific method, my conviction is that at present we have such uniformity and certainty only to a very limited extent and then usually by accident, father than as a result of conscious design.

It is difficult to find a modern judicial opinion which gives evidence that aur judges have more than a budding consciousness of the scientific method of use of systematized endeavor in theif intellectual activities, All is the crudest kind of empiricism with

28 Fortescue's Preface to his "Reports", p. III-IV.

${ }^{24}$ Locke here requoted from "Observations On the Nature of Civil Liberty", by Richard Hay, p. 37-38.

${ }^{25}$ Lord Camden, requoted from Russell's Eng. Const., 241. 
a manifest unconsciousness of the nature, or even of the existence of a scientific method.

In consequence of this I do not believe that the recall will make matters any worse, but rather better, because it will perhaps impress the judges at times with the necessity of doing a little more careful thinking and inquiring if their reasoning will seem to others justified-is it justified? I can perhaps illustrate what I mean by repeating a statement I often heard among lawyers in the middle west. It was said that anybody would clo as a justice of the court of last resort because he had the last guess, but it required a superior lawyer to make a creditable record as a justice of the peace.

When $I$ read the extravagant prophecies of disaster which are to follow if juclges in their official conduct are made as dependent as the legislators, I refuse to be frightened, becausc all those threats of disaster were made when it was first proposed to "destroy the independency of parliament" in England, by making its members responsible to the electorate, and "degrading" these officials by having them appeal for votes on definite programs for legislation. When I read the equally extravagant promises made by advocates of the recall, I also refuse to be impressed, because I see that for a century our legislators have been just as subservient to the money-power as were the members of England's parliament when they were not making "appeals to the rabble."

No! The recall will do neither the harm nor the good that is prophesied, but it is coming. It is coming because it is in line with the slowly progressing clemocratization of human institutions and therefore right. What good it will do will not be of the kind prophesied, but will come by indirection. It will tend to make judges more thoughtful and give voters an interest and opportunity for more enlightenment as to their relations to their fellow men. As an educational force slowly and in the long run it will do good, and in my judgment aside from this it will do little of either good or harm.

New York City. 